\title{
Tracing the Boundaries of the Unfathomable: An Introduction to Civilizations of the Supernatural
}

It is well known how phenomenologists of religion, first of all Gerardus Van der Leeuw and Mircea Eliade, have traditionally seen religion as a specifically (if not a "universally") human phenomenon. According to this view, the homo religiosus could be considered another typical model of humanity, along with the homo faber and the homo ludens, and one to be especially put in relation to the homo symbolicus, given the specific attitude of religious thinking to express itself through symbols. ${ }^{1}$ More recently, the application of cognitive science to the magico-religious domain has come up with intriguing considerations concerning the idea that there is something ingrained in the human mind that contributes to defining and orienting the search for the supernatural. The assertion that the human mind possesses "specified cognitive modules" or "hard-wired specialized subsystems" has been put in relation with the hypothesis that beliefs and behaviors related to the supernatural fit humans in a specific way. Justin Barrett's concept of the "Agency Detection Device," or the animal/human constitutive ability to relate an event to an agent, and Eugene Subbotsky's claim that the mind "naturally" divides reality into ordinary and magical domains, open the way to avenues of research intersecting the cultural and the cognitive that still need to be fully explored. ${ }^{2}$ After all, we have been reminded of how "religion in some sense is one of the earliest special proclivities that we are able to detect in the archaeological record of modern humans." 3 The intriguing thing would be to see how that "special proclivity" moves through the ages,

\footnotetext{
1 Julien Ries, L'Homo religiosus et son expérience du sacré: introduction à une nouvelle anthropologie religieuse (Paris: Cerf, 2009), 297.

2 See Edward Bever, "Current Trends in the Application of Cognitive Science to Magic," Magic, Ritual, and Witchcraft 7:1 (2012): 3-18.

${ }^{3}$ Ian Tattersall, Becoming Human: Evolution and Human Uniqueness (New York: Harcourt Brace, 1998), 201.
} 
apparently as a sort of subterranean stream, to surface in various and persistent political, anthropological, and literary forms.

This volume, Civilizations of the Supernatural: Witchcraft, Ritual, and Religious Experience in Late Antique, Medieval, and Renaissance Traditions, as its title already shows, aims at dissecting and discussing the role played by the relationship between men and the supernatural, in its various magical, ritualistic, and religious acceptations, as a typical cultural trait between the late-antique and the renaissance periods. I do not take the term civilization as a synonym for progress, as it is often the case with this concept; rather, I prefer to use the English civilization as an equivalent for the German kultur: a good example of this is represented by Jacob Burckhardt's Die Kultur der Renaissance in Italien, which has been translated into English as The Civilization of the Renaissance in Italy. Lucien Febvre distinguished between two different notions of civilization. One relies on an "ethnographical conception" which would include "all the features that can be observed in the collective life of one human group," and the other is based on an idea of "progress, failures, greatness and weakness" concerning which "we do have a value judgement in mind": this in turn would lead one to discriminate between what is "in itself great and beautiful" - i. e. civilization - and what on the contrary is "outside of it - savagery, barbarity or semi-civilization." 4 I have no doubts that the domain of the supernatural needs to be considered as an integral part of the first notion of civilization.

The present volume aims at advancing knowledge with regard to issues pertaining to what we would define as cultural history, intellectual history, history of ideas, and history of mentalities, by exploring symbols, representations, languages, and discourses related to time-frames and topics only apparently distant one from the other. Speaking of periodization, and relating it to the idea of the "evolution of societies," Jacques Le Goff in his last work reminded us how "it contains also the idea of transition, of one thing turning into another." 5 The chronological span covered by the studies gathered in this volume highlights precisely how there is often no real distance, neither in time nor in space, between cultural items: quite uniquely, the traditions related to religious

\footnotetext{
${ }^{4}$ Peter Burke, ed., A New Kind of History from the Writings of Febvre, trans. K. Folca (London: Routledge and Kegan Paul, 1973).

${ }^{5}$ Jacques Le Goff, Must We Divide History Into Periods?, trans. Malcolm DeBevoise (New York: Columbia University Press, 2015), 2.
} 
experience, magic ritual, and witchcraft have been living, developing, and changing through the ages as well as through a constant dialogue among themselves.

Moreover, today's awareness concerning the role of the supernatural in the life of individuals, societies, and cultural systems seems to be unprecedently on the rise. The "disenchantment of the world," predicted by Max Weber more than a century ago, has not happened yet. ${ }^{6}$ Rationality has certainly advanced, but the attitude of men and societies towards confronting themselves with the supernatural has not diminished; on the contrary, religious issues have been getting progressively more present at the social and international level as an absolutely challenging factor. ${ }^{7}$ Moreover, if it is true that cases of witchcraft are still widespread, especially in developing countries of Africa and Asia, we know how the resurgence of belief in witchcraft and the power of malevolent magic is a phenomenon that has been statistically detected in Europe and the U.S. With these premises in mind, it seems to be even more timely to foster a research into the historic roots of magico-religious beliefs and traditions.

Civilizations of the Supernatural tries to tackle the role of the magic, religious, and witchcraft-related traditions in shaping the intellectual and the historical identities of Western Europe between late antiquity and the early modern times. This is, to be sure, explicative of the more general aim of Trivent's new series Advances in the History of Magic, Witchcraft, and Religion, of which this is the first volume. We know how discourses relative to religion played a primary role in orienting not only the imagination and the everyday life of westerners, but also the formation of political and social structures as well as power relations. The cultural genesis of Europe itself, based on Graeco-Roman roots, would be unimaginable without the recourse to the religious element. For the Romans, religio was the guarantee of the balance between the juridical and the historical spheres: from the beginning, the roman pontifices were responsible for drafting both juridical and annalistic texts as well as, clearly, for maintaining the pax deorum as a pact between humans and deities, with the ius divinum being a part of the ius civilis. The exchange

\footnotetext{
${ }^{6}$ Max Weber, "Science as a Vocation," in From Max Weber: Essays in Sociology, ed. Hans H. Gerth and C. Wright Mills, 2nd repr. (London: Routledge, 1998), 129-56.

${ }^{7}$ See for instance John Micklethwait and Adrian Wooldridge, God is Back: How the Global Revival of Faith is Changing the World (New York: Penguin, 2009).
} 
between the human and the supernatural took the form of the civic religion, and it was that exchange that played a decisive role in shaping western civilization as we know it. ${ }^{8}$

Defining what religious experience is could be tricky. One should, first of all, take into consideration the concept of religion itself. Clifford Geertz's quite popular definition of religion seems to be particularly interesting, although apparently not complete. According to Geertz: "religion is (1) a system of symbols which acts to (2) establish powerful, pervasive, and long-lasting moods and motivations in men by (3) formulating conceptions of a general order of existence and (4) clothing these conceptions with such an aura of factuality that (5) the moods and motivations seem uniquely realistic." We immediately notice that this definition does not make reference to beliefs in gods; however, the accent put on the cultural aspects of religion (such as, first of all, the role of symbols) describes it as a peculiarly human phenomenon directly related to one of the core aspects in the shaping of civilizations. Émile Durkheim's definition is more specific and bound to social ground. According to him: "A religion is a unified system of beliefs and practices relative to sacred things, that is to say, things set apart and forbidden beliefs and practices which unite into one single moral community called a Church, all those who adhere to them." 10 Various elements should be noted here. First of all, the mention of beliefs and practices that form a moral community, which in turn can become a Church. This leads us towards the idea that religion creates something official and institutional or something that officially and institutionally binds, morally, an entire community. The reference to "sacred things" is also interesting: their being, according to the French sociologist, "set apart and forbidden" can point to a reality separated from everyday life, although as we have seen, all this can be used to shape moral - therefore social - communities. The characteristic of the sacred could be conceived of as a non-ordinary reality, something "set apart," as Durkheim says, something to be distinguished by what Alfred Schutz calls "the paramount reality," that

8 Cf. Jörg Rüpke, Pantheon: A New History of Roman Religion, trans. David M. B. Richardson (Princeton: Princeton University Press, 2018), 118-122.

${ }^{9}$ Clifford Geertz, "Religion as a Cultural System," in The Interpretation of Cultures (New York: Basic Books, 1973 [1966]), 90.

${ }^{10}$ Émile Durkheim, The Elementary Forms of Religious Life, trans. Karen E. Fields (New York: Free Press, 1995 [1912]), 44. 
of "daily life," and at the same time existing in strict relationship with it, describing a net of "multiple realities" in permanent communication with one another. ${ }^{11}$ The communication and the intersection between parallel realities as well as the trespassing of borders delimitating those realities with the rules governing, forbidding, or monopolizing such trespassing are the principles shaping not only religious experience, but also magic activities and beliefs in witchcraft.

Religion, as an official system determining the relationships of humans with the supernatural, has never been alone in the pursuit of orienting individuals as well as communities towards that aim. We have been reminded of the "change of paradigm" that at the beginning of the classical times led magic to become "an autonomous domain within religious practice." 12 Such domains, later seen by some elites as nonadmissible forms of interaction with the forces of nature, which were in turn perceived as overseeing the mysteries of human life, kept developing through the ages. The process which creates boundaries between beliefs and rituals considered to be acceptable or well-performed and those to be left out of that line of demarcation, in itself a sort of normative process, becomes evident in the late antique period, with the advent of Christianity and its installation onto the structures - both political and cultural - of the Roman Empire. Such a constantly changing and virtually never-ending process aimed at dragging the supernatural into history and at keeping its multifaceted nature under control would shape cultural traditions, individual values, and social models.

Ritual was part of both the religious systems and magical contexts as a means of interacting with the supernatural or, better, to bind it to the human domain. Thus, in tribal societies, if well performed, ritual fosters the energy and solidarity of the group. This can happen as "both tribal and archaic religions are cosmological, in that supernature, nature, and society were all fused in a single cosmos."13 We can agree, I believe, that a consideration of this kind might also apply to pre-modern, western

11 Alfred Schutz, "On multiple realities," in Collected Papers, Vol. I: The Problem of Social Reality, ed. M. Natanson (The Hague: Nijhoff, 1967), 207-259.

${ }^{12}$ Fritz Graf, Magic in the Ancient World, trans. Franklin Philip (Cambridge, MA: Harvard University Press, 1997), 30.

13 Robert N. Bellah, Religion in Human Evolution: From the Paleolithic to the Axial Age (Cambridge (MA); London: The Belknap Press of Harvard University Press, 2011), 265266. 
societies. In late antiquity, rituals were among those means employed by different religious groups competing for those holding the most efficient protection against daimones.

From being a means of protection, the ritual could also become an instrument for harming others. The presence of ritual - of demonic nature, to be sure - would certify in the Middle Ages certain types of malevolent magic, such as necromancy, which, as Michael Bailey reminds us, "by the later medieval period [...] had expanded to encompass any kind of ritual demonic conjuration and designated a whole category of elite, learned magic"."14 That is one of the elements distinguishing frivolous superstition - another problematic term generally pointing to beliefs or behaviours considered to pervert religion - from more serious, powerful, and potentially threatening forms of magic. As I have written elsewhere, the use of ritual outside of the official religious systems could be seen with suspicion because of "the role that rites and ritualized actions had in constructing community identity in closed and hierarchical societies." 15 This is also true as far as the complex phenomenon of witchcraft is concerned. We know how the shaping of a ritualistic nature of superstitious beliefs, with the accusation of invoking demons, would become one of the representative features of the shift from sorcery to witchcraft completed by the fifteenth century. At the same time, the learned models and popular narratives as well as the literary traditions whose fundamental role in shaping witch-beliefs have been highlighted, open up the way towards the consideration of belief in witchcraft as a transversal presence in time and among cultures. ${ }^{16}$

The studies in this volume - as well as the new book series in which this volume is published - need to be contextualized along this path

\footnotetext{
14 Michael D. Bailey, Fearful Spirits, Reasoned Follies: The Boundaries of Superstition in Late Medieval Europe (Ithaca: Cornell University Press, 2013), 22.

${ }^{15}$ Fabrizio Conti, Witchcraft, Superstition, and Observant Franciscan Preachers: Pastoral Approach and Intellectual Debate in Renaissance Milan (Turnhout: Brepols, 2015), 228. For a thorough reflection on superstition, see Stephen Anthony Smith, "Introduction," in The Religion of Fools? Superstition Past and Present, ed. Stephen Anthony Smith and Alan Knight (Oxford: Oxford University Press, 2008), 7-55.

${ }^{16}$ Cfr. Michael D. Bailey, "From Sorcery to Witchcraft: Clerical Conceptions of Magic in the Later Middle Ages," Speculum 4 (2001): 960-90; Gábor Klaniczay, "Learned Systems and Popular Narratives of Vision and Bewitchment," in Demons, Spirits, Witches, 3: Witchcraft Mythologies and Persecutions, ed. Gábor Klaniczay and Éva Pócs (Budapest: CEU Press, 2008), 50-82; Marina Montesano, Classical Culture and Witchcraft in Medieval and Renaissance Italy (Cham: Palgrave, 2018).
} 
leading the reader to discover and discuss diversity as well as recurrence in the history of ideas. Categories such as ritual, magic, witchcraft, and religious beliefs - as well as the concept of disbelief - are dealt with from diverse angles in the chapters of this volume and are shown as emerging in different ways according to the time-periods and the cultural contexts considered. The content of the volume is diverse enough to include late antique traditions covering erotic love magic (Naomi Janowitz), Hellenistic-Egyptian astrology (Attilio Mastrocinque), apotropaic rituals (Tiana Blazevic), early Christian amulets (Joseph Sanzo), and astrological amulets (Paolo Vitellozzi); medieval traditions focusing on the relationships between magic and disbelief (Michael Bailey), pagan magic and Christian culture (Martina Lamberti), witchcraft and magic in Britain (Francesco Marzella), Scandinavian sympathetic graphophagy (Andrea Maraschi), and superstition in sermon literature (Ewelina Kaczor); and finally Renaissance traditions revolving around Agrippan magic (Noel Putnik), witchcraft in Shakespeare's Macbeth (Melissa Pullara), and a Biblical toponym related to the Friulan Benandanti's visionary experiences (Cora Presezzi). These varied topics might be considered the prismatic sides of the same cube or the multifaceted ways through which men aimed to establish and delineate relationships with the supernatural - under the species of magic, rituals, religious views, and witch-beliefs with the aid of different means - whether literary texts, treatises, amulets, papyri or other - in diverse cultural traditions, and for different purposes, between the late antiquity and the Renaissance. This would eventually contribute to shaping the civilizations of the supernatural: peculiar views - with the worlds they have created - through which men have been looking at themselves in the mirrors of their marvels at being in this world, or if you will, paraphrasing Teofilo Ruiz's words, patterns for coping with the uncertainties of life throughout history. ${ }^{17}$

Fabrizio Conti

John Cabot University

${ }^{17}$ Cf. Teofilo F. Ruiz, The Terror of History: On the Uncertainties of Life in Western Civilization (Princeton: Princeton University Press, 2011), 40. 